\title{
Edible Lily Bulb Modulates Colonic Barrier Functions, Microflora and Fermentation in Rats Fed a High-Fat Diet
}

\author{
Yukako Okazaki $^{1 *}$, Eri Fukuda ${ }^{1}$, Hideyuki Chiji ${ }^{1}$ and Norihisa Kato ${ }^{2}$ \\ ${ }^{1}$ Faculty of Human Life Sciences, Fuji Women's University, Japan \\ ${ }^{2}$ Graduate School of Biosphere Science, Hiroshima University, Japan
}

\begin{abstract}
Received: December 12, 2013; Accepted: January 30, 2014; Published: February 13, 2014
*Corresponding author: Yukako Okazaki, Faculty of Human Life Sciences, Fuji Women's University, Ishikari, 061-3204, Japan, Tel: +81-133-747498; Fax: +81-133-74-7498; E-mail: yokazaki@fujijoshi.ac.jp
\end{abstract}

\begin{abstract}
Lily bulb (Lilium leichtlinii var. maximowiczii Baker) is traditionally consumed in Asia as both a root vegetable and a herbal medicine. The objective of this study was to determine if dietary edible lily bulbs modulated the colonic luminal environment in rats fed a high-fat (HF) diet. In experiment 1 , male SD rats were fed a HF diet ( $30 \%$ beef tallow) with or without $5 \%$ or $10 \%$ raw lily bulb powder for 3 weeks. Dietary raw lily bulb significantly increased cecal and fecal mucins, IgA (indices of intestinal barrier and immune functions) and the cecal ratio of Lactobacillales and Bifidobacterium in a dose-dependent manner. In experiment 2 , the rats were fed a $\mathrm{HF}$ diet with or without $7 \%$ steamed or raw lily bulb powder for 3 weeks. Cecal ratio of Lactobacillales was significantly increased in the $\mathrm{HF}+$ raw lily bulb group, with a similar trends being observed in the HF + steamed lily bulb group. Consumption of both steamed and raw lily bulb caused markedly increases in cecal and fecal mucins and cecal organic acids, including lactate, propionate, acetate, and butyrate. Unexpectedly, HF + steamed lily bulb diet caused a significant reduction in the fecal activity of mucinase, a risk factor for colon diseases, and mesenteric adipose tissue weight, whereas the $\mathrm{HF}+\mathrm{raw}$ lily bulb diet did not. These results suggest a favorable effect of lily bulb on colon health by modulating colonic barrier function, microflora profile, and fermentation in rats fed a high-fat diet.
\end{abstract}

Keywords: Lily bulb; Mucins; Cecal microflora; Cecal organic acids; Rats

\section{Introduction}

The Maximowicz's lily (Lilium leichtlinii var. maximowiczii Baker) belongs to the genus Lilium of the family Liliaceae. Its bulbs have been traditionally consumed in Asia as a root vegetable for hundreds of years. Edible lily bulb contains physiologically active components, such as dietary fibers, flavonoids, and saponins and is also rich in nutrients including starch and protein [15]. Lily bulb has been reported to contain around 20\% highmolecular weight $(\mathrm{MW}=230 \mathrm{kDa}$ ) glucomannan per dry weight, which consists of D-glucose and D-mannose units joined by $\beta$-glycosidic bound linkages [4]. Lily bulb has been also used in herbal medicine for the treatment of chronic gastritis, chronic bronchitis, pertussis and sedative, and it is assumed that lily bulb has physiological and pharmacological actions [6]. Recent in vitro studies [5,6] already showed that methanol extracts of lily bulbs have anti-inflammatory and antioxidant activities. However, few studies have examined the other nutritional and physiological properties of the lily bulb.

Consumption of certain dietary fibers has been reported to increase intestinal mucins and IgA concentrations, both of which play a role in the maintenance of gut barrier function and health $[7,8]$. The increased production of mucins and IgA has been considered to be associated with a lower risk of colon cancer $[9,10]$. Consumption of dietary fiber has also been reported to reduce fecal activity of mucinase, which degrades the protective mucin coat in the gut wall, thereby exposing colonic mucosal cells to toxic and carcinogenic substances [11,12]. Several types of dietary fibers and low digestible starch are known to modulate colonic microflora profile, and promote the organic acid fermentation [13-16]. Increases in the beneficial bacteria, such as lactobacilli and bifidobacteria, and in the organic acid such as butyrate and propionate were also associated with a reduced risk of colon cancer and ulcerative colitis [17-19].

Meanwhile, consumption of a high-fat (HF) diet increases mucinase activity, alters the composition of microflora, and decreases organic acids fermentation $[11,20]$. Therefore, a HF diet is suggested to be a risk factor for colon diseases such as colon cancer and ulcerative colitis [21,22]. Lily bulbs contain large amounts of dietary fibers and starch, and have been used as herbal medicine for the treatment of gut inflammation. Therefore, edible lily bulb could ameliorate colonic luminal environment under the high-fat diet condition. Several recent studies examined the effect of some functional food, such as mushroom and konjac, on colon health $[23,24]$. In the present study, we examined if dietary supplementation with lily bulb powder could affect colonic luminal variables, including mucins, IgA, enzyme activity, microflora, and organic acids in rats fed a HF diet.

\section{Materials and Methods \\ Preparation of the lily bulbs}

Lily bulbs were purchased from JA Youtei (Hokkaido, Japan). The cloves of raw lily bulb were peeled and freeze-dried. This 
lyophilized sample was powdered to produce raw lily bulb powder. Steamed lily bulb powder was prepared as follows: The lily bulb cloves were peeled and steamed for 25 min using an electric steamer (Groupe SEB Japan Co., Ltd., Tokyo, Japan). The steamed sample was powdered after being freeze-dried. The composition of the raw and steamed lily bulb powders is shown in Table 1. In experiment 1, the amount of dietary fibers in the raw lily bulb was measured using an enzyme-gravimetric method [25]. In experiment 2, the dietary fibers, in the raw and steamed lily bulb, including low molecular weight soluble dietary fibers were measured using the enzyme-gravimetric method in combination with HPLC (AOAC method 2001.03) [26].

\section{Animals and diets}

Four-wk old male Sprague Dawley (SD) rats were purchased from Japan SLC, Inc. (Hamamatsu, Japan) and maintained according to the "Guide for the Care and Use of Laboratory Animals" established by Fuji Women's University and approved by the ethics committee of the same university. The rats were individually housed in an air-conditioned room at $23-24^{\circ} \mathrm{C}$ and $50 \%-60 \%$ relative humidity, with 12 -h light cycle (light, 08:0020:00 h). The rats were acclimated by feeding a nonpurified commercial rodent powder diet (CE-2; CLEA Japan, Inc., Tokyo, Japan) for $6 \mathrm{~d}$, before commencing the experimental diet. In experiment 1 , the rats after acclimatization were divided into three groups of 8 rats each and assigned to a HF $(30 \%, w / w)$ diet or the same diet containing $5 \%$ or $10 \%$ raw lily-bulb powder. In experiment 2 , the rats after acclimatization were divided into three groups of 8 rats each and assigned to a HF (30\%,w/w) diet, with or without $7 \%$ raw or steamed lily bulb powder. The composition of the experimental diets is shown in Table 2. The levels of dietary carbohydrate, protein, fat, minerals, and fibers in the raw and steamed lily bulb diets were adjusted by reducing the amount of dietary corn starch, casein, beef tallow, and cellulose. To prevent difference in food intake, equal amounts of the experimental diets were provided daily in food cups at 19:00 (9 g for day $1,10 \mathrm{~g}$ for days 2-4, $12 \mathrm{~g}$ for days $5-7,14 \mathrm{~g}$ for days $8-13$, and $15 \mathrm{~g}$ for day 14-21). The entire amount of food provided was consumed each day before the next day's food was provided. The

Table 1: Chemical composition (\%,w/w) of raw and steamed lily bulb powders .

\begin{tabular}{|c|c|c|c|}
\hline \multirow{2}{*}{ Composition } & \multirow{2}{*}{\begin{tabular}{|l|} 
Experiment 1 \\
Raw lily bulb \\
\end{tabular}} & \multicolumn{2}{|c|}{ Experiment 2} \\
\hline & & Raw lily bulb & Steamed lily bulb \\
\hline Carbohydrate $^{\mathrm{b}}$ & 63.6 & 63.4 & 62.3 \\
\hline $\operatorname{Protein}^{c}(\mathrm{~N} \times 6.25)$ & 9.1 & 8.1 & 8.6 \\
\hline $\mathrm{Fat}^{\mathrm{d}}$ & 0.7 & 1.0 & 0.9 \\
\hline Dietary fibers ${ }^{\mathrm{e}}$ & 19.8 & 21.9 & 23.3 \\
\hline $\operatorname{Ash}^{\mathrm{f}}$ & 4.0 & 3.8 & 3.5 \\
\hline
\end{tabular}

aDuplicate analysis by The Foundation of Japan Food Research

Laboratory, Chitose, Japan.

b100 g - (protein + fat + dietary fibers + ash + water).

cKjeldahl method.

${ }^{\text {d}}$ Soxhlet method.

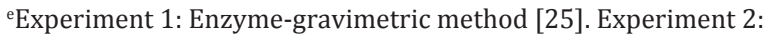

Enzyme-gravimetric-HPLC method [26].

fDirect incineration method.
Table 2: Composition of the experimental diet.

\begin{tabular}{|l|c|c|c|c|c|}
\hline & $\begin{array}{c}\text { Experi- } \\
\text { ment 1, 2 }\end{array}$ & \multicolumn{2}{|c|}{ Experiment 1 } & \multicolumn{2}{c|}{ Experiment 2 } \\
\cline { 2 - 6 } $\begin{array}{c}\text { Ingredient } \\
\text { (\%, w/w) }\end{array}$ & HF & $\begin{array}{c}\text { HF + 5\% } \\
\text { raw lily } \\
\text { bulb }\end{array}$ & $\begin{array}{c}\text { HF + 10\% } \\
\text { raw lily } \\
\text { bulb }\end{array}$ & $\begin{array}{c}\text { HF + } \\
\mathbf{7 \%} \\
\text { raw } \\
\text { lily } \\
\text { bulb }\end{array}$ & $\begin{array}{c}\text { HF + 7\% } \\
\text { steamed } \\
\text { lily bulb }\end{array}$ \\
\hline Casein & 20.0 & 19.6 & 19.1 & 19.4 & 19.4 \\
\hline L-Cystine & 0.3 & 0.3 & 0.3 & 0.3 & 0.3 \\
\hline Beef tallow & 30.0 & 30.0 & 29.9 & 29.9 & 29.9 \\
\hline Cellulose Powder & 5.0 & 4.0 & 3.0 & 3.5 & 3.4 \\
\hline $\begin{array}{l}\text { Vitamin mix } \\
\text { (AIN-93) }\end{array}$ & 1.0 & 1.0 & 1.0 & 1.0 & 1.0 \\
\hline $\begin{array}{l}\text { Mineral mix } \\
\text { (AIN-93G) }\end{array}$ & 3.5 & 3.5 & 3.5 & 3.5 & 3.5 \\
\hline Sucrose & 30.0 & 30.0 & 30.0 & 30.0 & 30.0 \\
\hline Corn starch & 10.2 & 6.7 & 3.2 & 5.4 & 5.5 \\
\hline Raw lily bulb & 0 & 5 & 10 & 7.0 & 0 \\
\hline Steamed lily bulb & 0 & 0 & 0 & 0 & 7.0 \\
\hline Net dietary fibers & 5.0 & 5.0 & 5.0 & 5.0 & 5.0 \\
\hline
\end{tabular}

HF = High Fat

weight of spilled diet was recorded daily and was included in the calculation of food intake. Feces were collected during the last 3 d. They were stored at $-20^{\circ} \mathrm{C}$ and then freeze-dried and milled. At the end of the feeding period, the rats were anesthetized with sodium pentobarbital and then killed by collection of whole blood from the abdominal aorta. The serum was separated at 2,000 $\times$ $\mathrm{g}$ for $20 \mathrm{~min}$ and stored at $-80^{\circ} \mathrm{C}$. The cecum, liver, and adipose tissues (epididymal, perirenal and mesenteric) were removed, weighed, frozen immediately with liquid nitrogen and stored at $-80^{\circ} \mathrm{C}$ for subsequent analysis.

\section{Measurements}

The mucins in cecal digesta and feces were extracted using the method of Bovee-Oudenhoven IM, et al. [27]. After extraction of the mucin fraction, the 0-linked oligosaccharide chains were quantitated using a fluorometric assay that discriminated between 0-linked glycoproteins (mucin) from N-linked glycoproteins [28]. Fecal mucinase activity was determined using previously described method [29].

Cecal and fecal IgA concentration was measured by ELISA using a Rat IgA ELISA quantitation kit (Bethyl Laboratories, Montgomery, Texas, USA) as according to the instructions of the manufacturer. Serum TNF- $\alpha$, IL-6, and lipopolysaccharidebinding protein (LBP) were determined using ELISA quantitation kits (a Kit for TNF- $\alpha$ manufactured by Sibayagi, Gunma, Japan, a kit for IL-6 manufactured by Immuno-Biological Laboratories Co. Ltd., Gunma, Japan and a kit for LBP manufactured by Biometec GmbH, Greifswald, Germany).

The $\mathrm{pH}$ of cecal digesta was measured directly using a compact pH meter (B-212; Horiba Ltd., Kyoto, Japan). Cecal microflora 
and organic acids were determined using the 16S rDNA based terminal restriction fragment length polymorphism (T-RFLP) analysis and HPLC method as described previously [20].

Serum triglyceride, total cholesterol, and HDL-cholesterol were quantified using enzymatic kits (Wako Pure Chemical Industries, Ltd., Osaka, Japan). Hepatic lipids were extracted by the method of Folch J, et al. [30] and quantified using enzymatic kits. The hepatic activities of glucose 6-phosphate dehydrogenase and malic enzyme were determined as previously described [31] Fecal triglyceride was measured using an enzymatic kit after lipid extraction according to the method of Folch J, et al. [30].

\section{Statistical analyses}

Data are expressed as the means \pm SEM. Data that followed a normal distribution were analyzed using one-way ANOVA and data that did not follow a normal distribution were analyzed by the nonparametric Kruskal-Wallis one-way ANOVA. The TukeyKramer post hoc-test was performed when a significant effect was determined by one-way ANOVA. Steel-Dwass post-hoc test was performed when a significant effect was found in the Kruskal-Wallis one-way ANOVA. The data were also analyzed using Spearman rank correlation analysis (Rs; Spearman rank correlation coefficient). All the analyses were performed using Excel Statistics 2010 for Windows (Social Survey Research Information Co., Ltd, Tokyo, Japan). Statistical significance for differences among means was estimated at $\mathrm{P}<0.05$.

\section{Results and Discussions}

\section{Experiment 1}

Food intake and final body weight did not differ between the $\mathrm{HF}$ and the $\mathrm{HF}+5 \%$ raw lily bulb groups, but were significantly lower in the group receiving $\mathrm{HF}+10 \%$ raw lily bulb powder than in the HF group $(\mathrm{P}<0.05$, Table 3$)$. The $\mathrm{HF}+10 \%$ raw lily bulb diet caused a significant increase in weight of pancreas, whereas the $\mathrm{HF}+5 \%$ raw lily bulb diet did not. Raw lily bulb is known to contain a trypsin inhibitor, which induces growth and food intake depressions and pancreatic enlargement in animals [32]. Therefore, the presence of excess trypsin inhibitor in the HF + $10 \%$ raw lily bulb diet, compared with that in the $\mathrm{HF}+5 \%$ raw lily bulb diet, may be associated with the depressions of growth and food intake, and increase in weight of the pancreas.

The cecal digesta weight was significantly higher in the group receiving $\mathrm{HF}+10 \%$ lily bulb powder than in that of the HF group ( $<<0.05$, Table 3 ). In addition, the group receiving $\mathrm{HF}+5 \%$ raw lily bulb powder had an intermediate in the cecal digesta weight. The $\mathrm{pH}$ of cecal digesta was significantly lower in the $\mathrm{HF}+5 \%$ and $\mathrm{HF}+10 \%$ raw lily bulb groups compared to the HF group $(\mathrm{P}<0.05)$. These results suggest that dietary raw lily bulb may increase intestinal fermentation. The fecal dry weight was unaffected by dietary treatment. Dietary raw lily bulb significantly increased cecal and fecal mucin content in a dose dependent manner (Table 4). Cecal IgA markedly increased in the $\mathrm{HF}+5 \%$ and $\mathrm{HF}+10 \%$ raw lily bulb groups in a dose dependent manner. Fecal IgA content was also significantly higher in the HF $+5 \%$ and $\mathrm{HF}+10 \%$ raw lily bulb groups than in the HF group (P
Table 3: Effect of dietary addition of $5 \%$ or $10 \%$ raw lily bulb on body weight, food intake, cecal and fecal weight in rats fed a HF diet ${ }^{1}$ (Experiment 1).

\begin{tabular}{|l|c|c|c|}
\hline & HF & $\begin{array}{c}\text { HF + 5\% } \\
\text { raw lily bulb }\end{array}$ & $\begin{array}{c}\text { HF + 10\% } \\
\text { raw lily bulb }\end{array}$ \\
\hline Initial body weight $(\mathrm{g})$ & $113 \pm 2$ & $113 \pm 2$ & $113 \pm 2$ \\
\hline Final body weight $(\mathrm{g})$ & $265 \pm 4^{\mathrm{a}}$ & $263 \pm 3^{\mathrm{a}}$ & $225 \pm 8^{\mathrm{b}}$ \\
\hline Food intake $(\mathrm{g} / 3 \mathrm{wk})$ & $270 \pm 5^{\mathrm{a}}$ & $275 \pm 2^{\mathrm{a}}$ & $235 \pm 7^{\mathrm{b}}$ \\
\hline Pancreas weight (\%) & $0.23 \pm 0.02^{\mathrm{b}}$ & $0.26 \pm 0.02^{\mathrm{ab}}$ & $0.35 \pm 0.03^{\mathrm{a}}$ \\
\hline Cecal digesta (g) & $1.74 \pm 0.19^{\mathrm{b}}$ & $2.15 \pm 0.18^{\mathrm{ab}}$ & $4.07 \pm 0.52^{\mathrm{a}}$ \\
\hline pH of cecal digesta & $7.00 \pm 0.12^{\mathrm{a}}$ & $5.91 \pm 0.22^{\mathrm{b}}$ & $5.41 \pm 0.18^{\mathrm{b}}$ \\
\hline Fecal dry weight (g/3 d) & $3.17 \pm 0.18$ & $3.41 \pm 0.10$ & $2.70 \pm 0.31$ \\
\hline
\end{tabular}

${ }^{1}$ Values are means \pm SEM, $n=8$. Means in a row with superscripts without a common letter (a, b) differ, $\mathrm{P}<0.05$ (Tukey-Kramer post-hoc test or Steel-Dwass test).

Table 4: Effect of dietary addition of $5 \%$ or $10 \%$ raw lily bulb on cecal and fecal mucins, IgA, and cecal microflora in rats fed a HF $\operatorname{diet}^{1}$ (Experiment 1).

\begin{tabular}{|c|c|c|c|}
\hline & HF & $\begin{array}{c}\text { HF + 5\% } \\
\text { Raw lily bulb }\end{array}$ & $\begin{array}{c}\text { HF }+10 \% \\
\text { Raw lily bulb }\end{array}$ \\
\hline $\begin{array}{l}\text { Cecal mucins (mg/ } \\
\text { total wet cecal } \\
\text { digesta) }\end{array}$ & $0.55 \pm 0.09^{c}$ & $1.44 \pm 0.20^{\mathrm{b}}$ & $6.10 \pm 0.95^{\mathrm{a}}$ \\
\hline $\begin{array}{l}\text { Fecal mucins (mg/3 } \\
\text { d) }\end{array}$ & $0.71 \pm 0.13^{\mathrm{c}}$ & $5.01 \pm 0.80^{\mathrm{b}}$ & $14.3 \pm 1.5^{\mathrm{a}}$ \\
\hline $\begin{array}{l}\text { Fecal mucinase } \\
\text { (units } / 3 \mathrm{~d} \text { ) }\end{array}$ & $1.68 \pm 0.16$ & $1.83 \pm 0.15$ & $1.32 \pm 0.28$ \\
\hline $\begin{array}{l}\text { Cecal IgA (mg/total } \\
\text { wet cecal digesta) }\end{array}$ & $0.45 \pm 0.10^{c}$ & $1.89 \pm 0.51^{b}$ & $6.68 \pm 2.44^{\mathrm{a}}$ \\
\hline Fecal IgA (mg/3 d) & $1.07 \pm 0.18^{\mathrm{b}}$ & $3.03 \pm 0.51^{\mathrm{a}}$ & $7.42 \pm 3.23^{\mathrm{a}}$ \\
\hline Cecal microflora & \multicolumn{3}{|c|}{ Occupation ratio of phylogenetic groups (\%) } \\
\hline Lactobacillales & $7.18 \pm 1.65^{\mathrm{c}}$ & $18.6 \pm 3.3^{b}$ & $32.7 \pm 3.5^{\mathrm{a}}$ \\
\hline Bifidobacterium & $0.089 \pm 0.089^{b}$ & $0.662 \pm 0.151^{\mathrm{a}}$ & $1.032 \pm 0.158^{\mathrm{a}}$ \\
\hline Clostridium & $48.2 \pm 2.8$ & $51.7 \pm 4.1$ & $41.3 \pm 4.4$ \\
\hline
\end{tabular}

${ }^{1}$ Values are means \pm SEM, $n=8$. Means in a row with superscripts without a common letter $(\mathrm{a}, \mathrm{b}, \mathrm{c}$ ) differ, $\mathrm{P}<0.05$ (Tukey-Kramer post-hoc test or Steel-Dwass test).

$<0.05$ ). These results suggest that raw lily bulbs have a favorable effect on intestinal barrier and immune functions. The fecal activity of mucinase was unaffected by dietary raw lily bulbs. The $\mathrm{HF}+5 \%$ and $\mathrm{HF}+10 \%$ raw lily bulb diets contained $0.99 \%$ and $1.98 \%$ dietary fibers, respectively. These levels are below those required to increase the level of IgA and mucins $[7,8]$. The lily bulb samples using in this study contained raw starch and saponins as well as dietary fibers. Raw starch has relatively low digestibility and it has been suggested that undigested starch may increase intestinal production of mucins and IgA [15]. Furthermore, our recent experiment [33] showed that dietary saponins increased fecal mucins and IgA levels in rats fed a HF diet. Therefore, the promoting effect of dietary lily bulb on IgA and mucins might be complexly related to its dietary fibers, undigested starch, and saponins. Further study is necessary to confirm this possibility. 
The $\mathrm{HF}+5 \%$ and $\mathrm{HF}+10 \%$ raw lily bulb diets markedly increased the cecal ratio of Lactobacillales in a dose dependent manner $(\mathrm{P}<0.05$, Table 4$)$. The ratio of Bifidobacterium in the cecum was also elevated by dietary supplementation of $5 \%$ and $10 \%$ raw lily bulb. The cecal ratio of Clostridium was not significantly different among the three groups. These results provide evidence that consumption of raw lily bulb has a prebiotic effect. Cecal Lactobacillales significantly correlated with cecal mucins (Rs $=0.74, \mathrm{P}<0.001)$, fecal mucins (Rs $=0.71, \mathrm{P}<$ $0.001)$, cecal IgA (Rs $=0.56, \mathrm{P}<0.005)$, and fecal IgA (Rs $=0.46$, $\mathrm{P}$ $<0.05)$. It has been previously reported that lactobacilli increases the expression of intestinal mucin and prevents attachment of pathogenic bacteria [34]. The administration of lactic acid bacteria as Lactobacillus has also been shown to stimulate the IgA immune response in the gut [35]. Taken together, these results suggest the possibility that higher ratio of Lactobacillales in the groups receiving lily bulb may at least in part contribute to increases in the levels of intestinal mucins and IgA.

\section{Experiment 2}

Because lily bulb is usually consumed after heating, we further examined whether heating treatment of lily bulb, as well as raw lily bulb, could affect colonic luminal environment in rats fed a high-fat diet. In experiment 1 , the effect of $\mathrm{HF}+10 \%$ raw lily bulb group on colonic luminal environment was prominent compared with that of the $\mathrm{HF}+5 \%$ raw lily bulb group, whereas dietary 10 $\%$ lily bulb caused slight inhibitions of growth and food intake. Therefore, in the second experiment, the lily bulbs were added to $\mathrm{HF}$ diets at the level of $7 \%$ to avoid growth and food intake depressions. As expected, food intake and final body weight did not differ among the three groups (Table 5). Liver, pancreas, and fecal dry weights were also unaffected by dietary treatment. The wet weight of cecal digesta was markedly higher, and the $\mathrm{pH}$ of the digesta significantly lower in both the HF + raw and HF + steamed lily bulb groups than in the HF group $(\mathrm{P}<0.05)$. Both the steamed and lily bulb diets caused markedly increased in cecal and fecal mucin content compared with that in the HF diet $(\mathrm{P}<0.05$, Table 6$)$. In accordance with the experiment 1 , fecal IgA was significantly increased in the $\mathrm{HF}+$ raw lily bulb group $(\mathrm{P}<$ 0.05), with a similar trend being observed in the HF + steamed lily bulb group. These results suggest that heating treatment of lily bulb have also a favorable effect on the intestinal barrier and its immune functions. Interestingly enough, the fecal activity of mucinase was significantly reduced in the HF + steamed lily bulb group compared with the HF group $(\mathrm{P}<0.05$, Table 6$)$. The bacterial enzyme mucinase degrades the protective mucin coat in the gut wall, reduces barrier function, and therefore is considered a risk factor for colon cancer [12]. The results of our study suggest that the increase in the mucosal mucin barrier caused by the steamed lily bulb may be related, in part, to the inhibition of mucin degradation. Heat treatments of several vegetables have been reported to increase flavonoids contents and physiological activities [36-38]. Therefore, the enhanced flavonoids in steamed lily bulb might be associated with the suppression of mucinase activity. Further study is necessary to examine the molecular mechanism by which steamed lily bulb
Table 5: Effect of dietary addition of 7\% raw and steamed lily bulb on body weight, food intake, cecal and fecal weight and serum inflammatory parameters in rats fed a HF diet ${ }^{1}$ (Experiment 2).

\begin{tabular}{|l|c|c|c|}
\hline & HF & $\begin{array}{c}\text { HF + raw } \\
\text { lily bulb }\end{array}$ & $\begin{array}{c}\text { HF + steamed } \\
\text { lily bulb }\end{array}$ \\
\hline Initial body weight (g) & $103 \pm 3$ & $103 \pm 2$ & $103 \pm 2$ \\
\hline Final body weight (g) & $263 \pm 3$ & $259 \pm 2$ & $258 \pm 6$ \\
\hline Food intake (g/3 wk) & $279 \pm 0$ & $277 \pm 1$ & $274 \pm 5$ \\
\hline Pancreas weight (\%) & $0.23 \pm 0.02$ & $0.26 \pm 0.02$ & $0.22 \pm 0.01$ \\
\hline Cecal digesta (g) & $1.73 \pm 0.09^{\mathrm{b}}$ & $2.51 \pm 0.20^{\mathrm{a}}$ & $2.40 \pm 0.22^{\mathrm{a}}$ \\
\hline pH of cecal digesta & $6.90 \pm 0.16^{\mathrm{a}}$ & $5.99 \pm 0.19^{\mathrm{b}}$ & $6.20 \pm 0.12^{\mathrm{b}}$ \\
\hline Fecal dry weight (g/3 d) & $3.24 \pm 0.13$ & $3.23 \pm 0.10$ & $2.91 \pm 0.15$ \\
\hline Serm TNF- $\alpha$ (ng/L) & $15.4 \pm 0.8$ & $14.0 \pm 1.8$ & $12.1 \pm 1.5$ \\
\hline Serum IL-6 (ng/L) & $11.1 \pm 0.3$ & $11.8 \pm 0.6$ & $13.3 \pm 1.0$ \\
\hline Serum LBP (mg/L) & $2.31 \pm 0.34$ & $2.26 \pm 0.28$ & $2.43 \pm 0.30$ \\
\hline
\end{tabular}

${ }^{1}$ Values are means \pm SEM, $n=8$. Means in a row with superscripts without a common letter differ (a, b), $\mathrm{P}<0.05$ (Tukey-Kramer post-hoc test or SteelDwass test).

Table 6: Effect of dietary addition of 7\% raw and steamed lily bulb on cecal and fecal mucins, IgA and cecal microflora in rats fed a HF $\operatorname{diet}^{1}$ (Experiment 2).

\begin{tabular}{|c|c|c|c|}
\hline & HF & $\begin{array}{l}\text { HF + raw } \\
\text { lily bulb }\end{array}$ & $\begin{array}{c}\text { HF + } \\
\text { steamed } \\
\text { lily bulb }\end{array}$ \\
\hline $\begin{array}{l}\text { Cecal mucins (mg/total wet } \\
\text { cecal digesta) }\end{array}$ & $0.35 \pm 0.03^{b}$ & $1.09 \pm 0.17^{\mathrm{a}}$ & $1.05 \pm 0.27^{\mathrm{a}}$ \\
\hline Fecal mucins (mg/3 d) & $0.81 \pm 0.13^{\mathrm{b}}$ & $3.75 \pm 0.72^{\mathrm{a}}$ & $2.63 \pm 0.80^{\mathrm{a}}$ \\
\hline $\begin{array}{l}\text { Fecal mucinase (units/g } \\
3 \text { d) }\end{array}$ & $2.25 \pm 0.15^{\mathrm{a}}$ & $2.13 \pm 0.18^{\mathrm{a}}$ & $1.42 \pm 0.23^{\mathrm{b}}$ \\
\hline Fecal IgA (mg/3 d) & $0.69 \pm 0.08^{\mathrm{b}}$ & $2.64 \pm 0.34^{\mathrm{a}}$ & $1.69 \pm 0.73^{\mathrm{ab}}$ \\
\hline Cecal microflora & \multicolumn{3}{|c|}{ Occupation ratio of phylogenetic groups (\%) } \\
\hline Lactobacillales & $34.3 \pm 2.0^{\mathrm{b}}$ & $47.1 \pm 3.1^{\mathrm{a}}$ & $42.4 \pm 3.2^{\mathrm{ab}}$ \\
\hline Bifidobacterium & ND & $0.157 \pm 0.073$ & $0.060 \pm 0.018$ \\
\hline Clostridium & $31.0 \pm 2.0$ & $32.5 \pm 3.0$ & $29.8 \pm 2.9$ \\
\hline
\end{tabular}

${ }^{1}$ Values are means $\pm S E M, n=8$. Means in a row with superscripts without a common letter $(\mathrm{a}, \mathrm{b})$ differ, $\mathrm{P}<0.05$ (Tukey-Kramer post-hoc test or Steel-Dwass test). ND = not detectable

and its bioactive compounds suppress the enzyme activity, and to compare bacterial load in the raw and steamed lily bulbs.

The inflammatory cytokines, serum TNF $\alpha$ and IL-6 were both unaffected by the HF + raw and $\mathrm{HF}+$ steamed lily bulb diets (Table 5). The serum level of LBP, a pro-inflammatory LPS transporter used as a marker of endotoxemia [39], was also not different in the three groups. Therefore, the raw and steamed lily bulbs appear to modulate mucin and IgA levels in the gut without affecting inflammatory factors.

As in experiment 1 , the HF + raw lily bulb diet significantly 
increased cecal Lactobacillales $(\mathrm{P}<0.05)$, with similar trend being observed in the $\mathrm{HF}+$ steamed lily bulb group (Table 6). Bifidobacterium was detected in the cecum of the groups consuming $\mathrm{HF}+$ raw and HF + steamed lily bulbs, whereas it was hardly detected in the HF group. The cecal content of Clostridium was not different among the three groups. The present study demonstrated that the heat treatment of lily bulb also can modulate the cecal microflora profile.

We have previously demonstrated that a HF diet decreases fermentation of organic acids in the rat cecum [20]. This decrease in intestinal fermentation leads to a higher risk for colon diseases $[17,18]$. Because the HF + raw and HF + steamed lily bulb diets increased the weight of cecal digesta and decreased the $\mathrm{pH}$, we further investigated whether the bulbs affected cecal organic acids. The results demonstrated that both $\mathrm{HF}+$ raw and $\mathrm{HF}+$ steamed bulbs caused significant increases in cecal n-butyrate $(+253 \%$ and $+189 \%$, respectively), succinate $(+257 \%$ and $+378 \%$, respectively), lactate $(+286 \%$ and $+496 \%$, respectively), and total organic acids $(+169 \%$ and $+174 \%$ respectively) per $g$ wet cecal digesta $(\mathrm{P}<0.05$, Table 7$)$. Dietary raw and steamed lily bulbs caused significant increase in cecal acetate $(+201 \%$ and $+163 \%$, respectively), propionate $(+161 \%$ and $+171 \%$, respectively), n-butyrate $(+363 \%$ and $+253 \%$, respectively), lactate $(+388 \%$ and $+700 \%$, respectively) and total organic acids $(+242 \%$ and $+245 \%$, respectively) per total cecal digesta $(\mathrm{P}<0.05)$. When the data were expressed relative to total cecal digesta, the increase in cecal succinate level was prominent in the $\mathrm{HF}+$ steamed lily bulb group $(+556 \%)$. Because lactate and succinate are absorbed more slowly in the gut than other organic acids [40], the $\mathrm{pH}$ of cecal digesta is considerably lower, with this acidic environment favoring acid-resistant bacteria such as lactobacilli and bifidobacteria. Furthermore, organic acids such as butyrate, acetate, and propionate are also considered to play a key role in colonic health [13]. Dietary fibers and undigested starch have been reported to increase the levels of organic acids [11,13]. Kishida T, et al. [41] reported that a type of heatmoisture treated starch decreased enzymatic digestibility and increased the levels of cecal organic acids to the same degree as raw starch. Therefore, it is necessary to test whether dietary fiber and undigested starch in raw and steamed lily bulbs contribute to the observed effect on cecal organic acids.

Unexpectedly, the HF + steamed lily bulb diet caused a significant reduction in mesenteric adipose tissue weight ( $\mathrm{P}$ $<0.05$ ), whereas the HF + raw lily bulb diet did not cause any reduction (Table 8). The same tendency was observed for epididymal adipose tissue weight. Serum triglyceride, cholesterol and free fatty acids were unaffected by dietary treatment. Liver triglyceride, cholesterol, and the activities of glucose 6-phosphate dehydrogenase and malic enzyme were also unaffected. Therefore, these findings indicate that the suppressive effect of the steamed lily bulb on the adipose tissue weight cannot be explained by changes in hepatic lipogenesis. Consumption of steamed lily bulb significantly increased fecal excretion of triglyceride and neutral sterol $(\mathrm{P}<0.05)$, but the HF + raw lily bulb diet did not. It is therefore possible that the reduction in the adipose tissue weight
Table 7: Effect of dietary addition of 7\% raw and steamed lily bulb on cecal organic acids in rats fed a HF diet ${ }^{1}$ (Experiment 2).

\begin{tabular}{|l|c|c|c|}
\hline \multicolumn{1}{|c|}{ HF } & $\begin{array}{c}\text { HF + raw } \\
\text { lily bulb }\end{array}$ & $\begin{array}{c}\text { HF + steamed } \\
\text { lily bulb }\end{array}$ \\
\hline Organic acids & \multicolumn{3}{|c|}{$(\mu \mathrm{mol} /$ g wet cecal digesta $)$} \\
\hline Acetate & $31.3 \pm 2.7^{\mathrm{b}}$ & $43.4 \pm 2.0^{\mathrm{a}}$ & $37.5 \pm 4.5^{\mathrm{ab}}$ \\
\hline Propionate & $9.04 \pm 0.93$ & $10.06 \pm 0.92$ & $10.76 \pm 1.06$ \\
\hline n-butyrate & $6.80 \pm 1.07^{\mathrm{b}}$ & $17.18 \pm 2.12^{\mathrm{a}}$ & $12.88 \pm 1.50^{\mathrm{a}}$ \\
\hline Succinate & $8.1 \pm 1.5^{\mathrm{b}}$ & $20.8 \pm 4.8^{\mathrm{a}}$ & $30.6 \pm 6.4^{\mathrm{a}}$ \\
\hline Lactate & $1.37 \pm 0.27^{\mathrm{b}}$ & $3.92 \pm 0.95^{\mathrm{a}}$ & $6.79 \pm 1.91^{\mathrm{a}}$ \\
\hline Total organic acids & $56.6 \pm 4.7^{\mathrm{b}}$ & $95.4 \pm 4.3^{\mathrm{a}}$ & $98.6 \pm 5.9^{\mathrm{a}}$ \\
\hline & \multicolumn{2}{|c|}{$(\mu \mathrm{mol} /$ total wet cecal digesta) } \\
\hline Acetate & $53.4 \pm 4.9^{\mathrm{b}}$ & $107.3 \pm 7.6^{\mathrm{a}}$ & $87.2 \pm 9.3^{\mathrm{a}}$ \\
\hline Propionate & $15.3 \pm 1.3^{\mathrm{b}}$ & $24.7 \pm 2.5^{\mathrm{a}}$ & $26.1 \pm 3.3^{\mathrm{a}}$ \\
\hline n-butyrate & $11.7 \pm 1.8^{\mathrm{b}}$ & $42.5 \pm 5.6^{\mathrm{a}}$ & $29.6 \pm 3.3^{\mathrm{a}}$ \\
\hline Succinate & $14.2 \pm 3.0^{\mathrm{b}}$ & $51.5 \pm 11.2^{\mathrm{a}^{\mathrm{b}}}$ & $78.9 \pm 20.8^{\mathrm{a}}$ \\
\hline Lactate & $2.28 \pm 0.35^{\mathrm{b}}$ & $8.85 \pm 1.40^{\mathrm{a}}$ & $15.96 \pm 5.10^{\mathrm{a}}$ \\
\hline Total organic acids & $97 \pm 9^{\mathrm{b}}$ & $235 \pm 14^{\mathrm{a}}$ & $238 \pm 27^{\mathrm{a}}$ \\
\hline
\end{tabular}

${ }^{1}$ Values are means $\pm S E M, n=8$. Means in a row with superscripts without a common letter $(\mathrm{a}, \mathrm{b})$ differ, $\mathrm{P}<0.05$ (Tukey-Kramer post-hoc test or SteelDwass test).

Table 8: Effect of dietary addition of $7 \%$ raw and steamed lily bulb on lipid status in rats fed a HF diet ${ }^{1}$ (Experiment 2).

\begin{tabular}{|l|c|c|c|}
\hline \multicolumn{1}{|c|}{ HF } & $\begin{array}{c}\text { HF + raw } \\
\text { lily bulb }\end{array}$ & $\begin{array}{c}\text { HF + } \\
\text { steamed } \\
\text { lily bulb }\end{array}$ \\
\hline Serum & & & \\
\hline Triglyceride (mmol/L) & $2.73 \pm 0.38$ & $2.47 \pm 0.52$ & $2.68 \pm 0.98$ \\
\hline Total cholesterol (mmol/L) & $1.91 \pm 0.07$ & $1.87 \pm 0.07$ & $1.87 \pm 0.10$ \\
\hline HDL-cholesterol (mmol/L) & $0.80 \pm 0.03$ & $0.84 \pm 0.02$ & $0.80 \pm 0.03$ \\
\hline $\begin{array}{l}\text { VLDL + IDL + LDL-cholesterol } \\
\text { (mmol/L) }\end{array}$ & $1.08 \pm 0.06$ & $1.02 \pm 0.01$ & $1.04 \pm 0.02$ \\
\hline Atherogenic index 3 & $1.35 \pm 0.08$ & $1.22 \pm 0.08$ & $1.24 \pm 0.13$ \\
\hline Liver & & & \\
\hline Triglyceride ( $\mu$ mol/g tissue) & $208 \pm 37$ & $190 \pm 34$ & $232 \pm 46$ \\
\hline Cholesterol ( $\mu$ mol /g tissue) & $26.6 \pm 0.8$ & $24.0 \pm 1.0$ & $23.0 \pm 1.81$ \\
\hline G6PD activity (units/g tissue) & $2.54 \pm 0.26$ & $2.98 \pm 0.36$ & $2.58 \pm 0.24$ \\
\hline ME activity (units/g tissue) & $3.36 \pm 0.31$ & $3.74 \pm 0.32$ & $3.80 \pm 0.39$ \\
\hline Adipose tissue weight $(\%)$ & & & \\
\hline Mesenteric adipose tissue & $1.21 \pm 0.04^{\mathrm{a}}$ & $1.19 \pm 0.04^{\mathrm{ab}}$ & $1.05 \pm 0.05^{\mathrm{b}}$ \\
\hline Epididymal adipose tissue & $1.41 \pm 0.06^{\mathrm{ab}}$ & $1.58 \pm 0.09^{\mathrm{a}}$ & $1.26 \pm 0.09^{\mathrm{b}}$ \\
\hline Feces & & & \\
\hline Triglyceride $(\mu \mathrm{mol} / 3 \mathrm{~d})$ & $3.15 \pm 0.29^{\mathrm{b}}$ & $5.11 \pm 0.64^{\mathrm{ab}}$ & $5.35 \pm 0.66^{\mathrm{a}}$ \\
\hline Neutral sterol $(\mu \mathrm{mol} / 3 \mathrm{~d})$ & $29.2 \pm 3.6^{\mathrm{b}}$ & $31.5 \pm 2.1^{\mathrm{ab}}$ & $38.8 \pm 3.4^{\mathrm{a}}$ \\
\hline
\end{tabular}

${ }^{1}$ Values are means \pm SEM, $n=8$. Means in a row with superscripts without a common letter $(\mathrm{a}, \mathrm{b})$ differ, $\mathrm{P}<0.05$ (Tukey-Kramer post-hoc test).

${ }^{2} \mathrm{VLDL}+$ IDL + LDL-cholesterol were calculated as total cholesterol minus HDL-cholesterol.

${ }^{3}$ Atherogenic index was calculated as (total-cholesterol minus HDLcholesterol) /HDL-cholesterol

G6PD = Glucose 6-Phosphate Dehydrogenase; ME = Malic Enzyme. 
associated with the dietary steamed lily bulb may at least be mediated by a reduction in lipid absorption. Several studies have reported that heat treatments enhance flavonoids contents in vegetables [36,37]. Dietary flavonoids are known to suppress fat accumulation in obese animal [42]. Therefore, it is of interest to test the possibility that steam treatment may increase flavonoids contents in lily bulb, and the increase may be associated with the reduction of adipose tissue weight.

It has been recently suggested that obesity is related to dysbiosis of the gut microbiota [43]. Several studies [44,45] have shown a higher ratio of Firmicutes and reduction in the ratio of Bacteroidetes in overweight and obese animals than among lean animals. Further study is in progress in rats fed a HF diet to test whether dietary supplementation with steamed lily bulbs modulates the intestinal ratios of Firmicutes and Bacteroidetes, and whether this modulation is related to a decrease in the adipose tissue weight.

\section{Conclusion}

This study provides first evidence that dietary lily bulb increases the levels of intestinal mucin, IgA, cecal Lactobacillales and organic acid fermentation. An interesting finding in this study of rats fed a HF diet is that steam treatment of the lily bulbs significantly reduced mesenteric adipose tissue weight and fecal mucinase activity, a risk factor for colon cancer. These findings suggest that lily bulb can be considered as a novel functional food for colon health. Further studies are in progress to isolate the dietary fiber, low digestible starch, flavonoids, and sapponins from lily bulb that may be responsible for the functions described in this study.

\section{Acknowledgments}

This research was supported in part by a Grant-in-Aid for Young Scientists (B) (no. 24700845) from the Ministry of Education, Culture, Sports, Science and Technology of Japan.

\section{References}

1. Mullin WJ, Peacock S, Loewen DC, Turner NJ (1997) Macronutrients content of Yellow Glacier Lily and Balsamroot; root vegetables used by indigenous peoples of northwestern North America. Food Research International 30(10): 769-775.

2. Shin KS, Chakrabarty D, Paek KY (2002) Sprouting rate, change of carbohydrate contents and related enzymes during cold treatment of lily bulblets regenerated in vitro. Scientia Horticulturae 96(1-4): 195204.

3. Satou T, Mimaki Y, Kuroda M, Sashida Y, Hatakeyama Y (1996) A pyrroline glucoside ester and steroidal saponins from Lilium martagon. Phytochemistry 41(4):1225-1230.

4. Wozniewski T, Blaschek W, Franz G (1989) Physiologically active polysaccharides from lilium testaceum isolation and structural investigation. Planta Medica 55(7): 638.

5. Jin L, Zhang Y, Yan L, Guo Y, Niu L (2012) Phenolic compounds and antioxidant activity of bulb extracts of six Lilium species native to China. Molecules 17(8): 9361-9378.

6. Kwon OK, Lee MY, Yuk JE, Oh SR, Chin YW, et al. (2010) Antiinflammatory effects of methanol extracts of the root of Lilium lancifolium on LPS-stimulated Raw264.7 cells. J Ethnopharmacol 130(1): 28-34.

7. Yamada K, Tokunaga Y, Ikeda A, Ohkura K, Kaku-Ohkura S, et al. (2003) Effect of dietary fiber on the lipid metabolism and immune function of aged Sprague-Dawley rats. Biosci Biotechnol Biochem 67(2):429-433.

8. Hino S, Sonoyama K, Bito H, Kawagishi H, Aoe S, et al. (2013) Low-methoxyl pectin stimulates small intestinal mucin secretion irrespective of goblet cell proliferation and is characterized by jejunum Muc2 upregulation in rats. J Nutr 143(1):34-40.

9. Perdigón G, de Moreno de LeBlanc A, Valdez J, Rachid M (2002) Role of yoghurt in the prevention of colon cancer. Eur J Clin Nutr 56(3): S65-68.

10.Velcich A, Yang W, Heyer J, Fragale A, Nicholas C, et al. (2002) Colorectal cancer in mice genetically deficient in the mucin Muc2. Science 295: 1726-1729.

11. Wu WT, Chen HL (2011) Effects of konjac glucomannan on putative risk factors for colon carcinogenesis in rats fed a high-fat diet. J Agric Food Chem 59(3): 989-994.

12. Miller RS, Hoskins LC (1981) Mucin degradation in human colon ecosystems. Fecal population densities of mucin-degrading bacteria estimated by a "most probable number" method. Gastroenterology 81(4): 759-765.

13.Topping DL, Clifton PM (2001) Short-chain fatty acids and human colonic function: roles of resistant starch and nonstarch polysaccharides. Physiol Rev 81(3): 1031-1064.

14. Nyman M (2002) Fermentation and bulking capacity of indigestible carbohydrates: the case of inulin and oligofructose. Br J Nutr 87(2): S163-168.

15. Morita T, Tanabe H, Takahashi K, Sugiyama K (2004) Ingestion of resistant starch protects endotoxin influx from the intestinal tract and reduces D-galactosamine-induced liver injury in rats. J Gastroenterol Hepatol 19(3): 303-313.

16. Mei GY, Carey CM, Tosh S, Kostrzynska M (2011) Utilization of different types of dietary fibres by potential probiotics. Can J Microbiol 57(10): 857-865.

17.Wollowski I, Rechkemmer G, Pool-Zobel BL (2001) Protective role of probiotics and prebiotics in colon cancer. Am J Clin Nutr 73(2):451S-455S.

18. Scheppach W (1994) Effects of short chain fatty acids on gut morphology and function. Gut 35(1):S35-38.

19. Tang Y, Chen Y, Jiang H, Robbins GT, Nie D (2011) G-protein-coupled receptor for short-chain fatty acids suppresses colon cancer. Int J Cancer 128(4):847-856.

20. Okazaki Y, Tomotake H, Tsujimoto K, Sasaki M, Kato N (2011) Consumption of a resistant protein, sericin, elevates fecal immunoglobulin A, mucins, and cecal organic acids in rats fed a highfat diet. J Nutr 141(11):1975-1981.

21. Liu Z, Uesaka T, Watanabe H, Kato N (2001) High fat diet enhances colonic cell proliferation and carcinogenesis in rats by elevating serum leptin. Int J Oncol 19(5): 1009-1014.

22. Ma X, Torbenson M, Hamad AR, Soloski MJ, Li Z (2008) High-fat diet modulates non-CD1d-restricted natural killer T cells and regulatory $\mathrm{T}$ cells in mouse colon and exacerbates experimental colitis. Clin Exp Immunol 151(1): 130-138.

23.Varshney J, Ooi JH, Jayarao BM, Albert I, Fisher J, et al. (2013) White 
button mushrooms increase microbial diversity and accelerate the resolution of Citrobacter rodentium infection in mice. J Nutr 143(4): 526-532.

24. Young W, Roy NC, Lee J, Lawley B, Otter D, et al. (2013) Bowel microbiota moderate host physiological responses to dietary konjac in weanling rats. J Nutr 143(7):1052-1060.

25. Prosky L, Asp NG, Schweizer TF, DeVries JW, Furda I (1988) Determination of insoluble, soluble, and total dietary fiber in foods and food products: interlaboratory study. J Assoc Off Anal Chem 71(5): 1017-1023.

26. Gordon DT, Okuma K (2002) Determination of total dietary fiber in selected foods containing resistant maltodextrin by enzymaticgravimetric method and liquid chromatography: collaborative study. ] AOAC Int 85(2): 435-444

27. Bovee-Oudenhoven IM, Termont DS, Heidt PJ, Van der Meer R (1997) Increasing the intestinal resistance of rats to the invasive pathogen Salmonella enteritidis: additive effects of dietary lactulose and calcium. Gut 40(4): 497-504.

28. Crowther RS, Wetmore RF (1987) Fluorometric assay of O-linked glycoproteins by reaction with 2-cyanoacetamide. Anal Biochem 163(1): 170-174.

29. Shiau SY, Chang GW (1983) Effects of dietary fiber on fecal mucinase and $\beta$-glucuronidase activity in rats. J Nutr 113(1): 138-144.

30. Folch J, Lees M, Sloane-Stanley GH (1957) A simple method for the isolation and purification of total lipids from animal tissues. J Biol Chem 226(1): 497-509.

31. Freedland RA (1967) Effect of progressive starvation on rat liver enzyme activities. J Nutr 91(4): 489-495.

32. Zhang X, Wang H, Ng TB (2008) Isolation and characterization of a novel trypsin inhibitor from fresh lily bulbs. Planta Med 74(5): 546550

33. Utama Z, Okazaki Y, Tomotake H, Kato N (2013) Tempe consumption modulates fecal secondary bile acids, mucins, immunoglobulin $\mathrm{A}$, enzyme activities, and cecal microflora and organic acids in rats. Plant Foods Hum Nutr 68(2): 177-183.

34. Caballero-Franco C, Keller K, De Simone C, Chadee K (2007) The VSL\#3 probiotic formula induces mucin gene expression and secretion in colonic epithelial cells. Am J Physiol Gastrointest Liver Physiol 292(1): G315-322.
35. Yoshida Y, Tsukahara T, Ushida K (2009) Oral administration of Lactobacillus plantarum Lq80 and Megasphaera elsdenii iNP-001 induces efficient recovery from mucosal atrophy in the small and the large intestines of weaning piglets. Anim Sci J 80(6): 709-715.

36. Choi Y, Lee SM, Chun J, Lee HB, Lee J (2006) Influence of heat treatment on the antioxidant activities and polyphenolic compounds of Shiitake (Lentinus edodes) mushroom. Food Chem 99(2): 381-387.

37.Lombard K, Peffley E, Geoffriau E, Thompson L, Herring A (2005) Quercetin in onion (Allium cepa L.) after heat-treatment simulating home preparation. J Food Composition and Analysis 18(6): 571-578.

38. Moriyama H, Iizuka T, Nagai M, Miyataka H, Satoh T (2003) Antiinflammatory activity of heat-treated Cassia alata leaf extract and its flavonoid glycoside. Yakugaku Zasshi 123(7): 607-611.

39. Stenman LK, Holma R, Gylling H, Korpela R (2013) Genetically obese mice do not show increased gut permeability or faecal bile acid hydrophobicity. Br J Nutr 110(6): 1157-1164.

40. Hoshi S, Sakata T, Mikuni K, Hashimoto H, Kimura S (1994) Galactosylsucrose and xylosylfructoside alter digestive tract size and concentrations of cecal organic acids in rats fed diets containing cholesterol and cholic acid. J Nutr 124(1): 52-60.

41. Kishida T, Nogami H, Himeno S, Ebihara K (2001) Heat moisture treatment of high amylose cornstarch increases its resistant starch content but not its physiologic effects in rats. J Nutr 131(10): 27162721.

42. Nakagawa K, Kishida H, Arai N, Nishiyama T, Mae T (2004) Licorice flavonoids suppress abdominal fat accumulation and increase in blood glucose level in obese diabetic KK-A(y) mice. Biol Pharm Bull 27(11): 1775-1778

43. Cani PD, Delzenne NM (2009) Interplay between obesity and associated metabolic disorders: new insights into the gut microbiota. Curr Opin Pharmacol 9(6): 737-743.

44. Ley RE, Bäckhed F, Turnbaugh P, Lozupone CA, Knight RD, et al. (2005) Obesity alters gut microbial ecology. Proc Natl Acad Sci U S A 102(31): 11070-11075.

45. Ley RE, Turnbaugh PJ, Klein S, Gordon JI (2006) Microbial ecology: human gut microbes associated with obesity. Nature 444(7122): 1022-1023. 